\title{
Research on the Construction of Talent Training Plan for Civil Aviation Safety Technology Management Based on the Concept of "Integration of Curriculum and Certificate, Integration of Production and Teaching"
}

\author{
Hu Chengwei, Zhang Liang* \\ Guangzhou Civil Aviation College, Guangzhou, 510000 \\ 25267764@qq.com \\ Guangzhou Civil Aviation Vocational and Technical College, Guangzhou, Guangdong 510000
}

\begin{abstract}
Keywords: Integration of curriculum and certificate; Integration of production and education; civil aviation; talent training program; curriculum system; teaching security system
\end{abstract}

Abstract: The talent training program is a concentrated embodiment of the school-running philosophy and educational thoughts. It is an implementation plan to achieve the goal and specification of talent training. Based on an in-depth study of the civil aviation airport security inspection business's demand for talents, this paper formulates a civil aviation safety technology management professional training program based on the concept of the integration of curriculum and certificate and the integration of production and education; Analyzes the work tasks and professional capabilities of civil aviation airport security technology management positions; Establishes a systematic curriculum system for civil aviation safety technology management professionals; This paper expounds how to construct the teaching guarantee system based on the theory and method of "integration of curriculum and certificate, integration of production and teaching", and ensure the appropriateness of the training of civil aviation security and technical management professionals.

\section{Introduction}

Civil aviation safety inspection, referred to as civil aviation security inspection, it refers to a compulsory technical inspection of air defense that is implemented at civilian airports to prevent the occurrence of aircraft and other incidents that endanger aviation safety and to protect the safety of passengers, crew and aircraft. In recent years, with the rapid development of China's civil aviation industry and the rapid changes in the form of security at home and abroad, the challenges and impacts faced by China's civil aviation safety inspections have been continuously intensified. As the undertaking of civil aviation safety inspection, civil aviation safety inspection staff faces unprecedented challenges and pressures. Under this background, higher vocational colleges "professional civil aviation safety technology management" should be born, realize the "professional set up and industry demand closely docked", and then also face the problem of 
professional construction [1].

"Integration of curriculum and certificate" refers to personnel training standards linking with national vocational qualification standards, cultivating content to meet national vocational standards, and "integration of production and education" refers to that vocational schools actively set up professional industries according to their established specialties, and integrate industries and teaching closely. Support and promote each other, make the school an industrial business entity integrating talent training, scientific research, and science and technology services, and form a school-integrated school-running model. The civil aviation safety technology management professional training program is designed in strict accordance with the concept of "integration of curriculum and certificate, integration of production and teaching", which realizes the docking of professional and professional positions, the docking of teaching materials and posts, the docking of teaching process and production process, and the docking of academic certificates and industry standards, vocational education and lifelong learning docking talent training model.

\section{Current Situation of Talent Cultivation in Civil Aviation Safety Technology Management Professional}

In order to meet the demand of civil aviation professionals for security professionals, many higher vocational colleges have successively established civil aviation safety technology management professionals. The major is to cultivate the needs of civil aviation safety, with high political quality and good professional ethics and professionalism, with good physical and psychological qualities, with good English communication skills and computer application skills, mastering air defense security, civil aviation safety inspection policies and regulations and civil aviation knowledge, with basic policing professional skills required by security personnel, skilled use of various types of security equipment and equipment, with the good psychological quality and ability to deal with and dispose of civil aviation passengers through the emergencies encountered in the process of security inspection, and able to serve the national civil aviation security business with high-quality, self-improvement ability of high-quality, skilled airport safety inspection personnel. However, the current talent cultivation mainly has the following problems: (1) The development process of personnel training programs is simplified, and the research on job assignments and professional abilities is not thorough or comprehensive, resulting in a mismatch between professional orientation, talent training objectives, and industry needs; (2) the professional corresponding post group cognitive one-sided, failed to form an effective professional training model, teaching mode in the practical teaching process is poor; (3) the teaching content is too old, and the curriculum system is not scientific; (4) the lack of necessary practical teaching conditions, students' professional skills are difficult to achieve the training objectives.

\section{Design of Civil Aviation Safety Technology Management Talents Training Program Based on "Integration of Curriculum and Certificate, Integration of Production and Teaching"}

\subsection{Determination of Professional Orientation and Talent Cultivation Objectives}

The goal of personnel training is a guide for educational activities. It addresses the question of "what kind of person is being cultivated" and involves the basic scale of talent training [2]. The determination of civil aviation safety technology management personnel training objectives should consider the following aspects: First, reflect the directionality of professional services, that is, to cultivate which talents serve in the field of civil aviation safety; second, reflect the comprehensiveness of professional training, that is, the cultivated talents have various skills required for civil aviation safety inspection positions; third, reflect the development of professional 
training, that is, the cultivated talents have the ability to analyze comprehensive ability and logical thinking, and to achieve self-renewal and self-improvement in the future.

Based on this, we have positioned civil aviation safety technology management majors in the civil aviation transportation airport industry, mainly engaged in civil aviation airport passenger safety inspection, safety monitoring, management safety monitoring, etc., and mastered the basic theory of civil aviation laws and regulations, safety inspection services and safety precautions, etc. Knowledge and operating skills, with high-quality technical and technical talents such as passenger document inspection, passenger hand baggage inspection, and passenger checked baggage inspection, passenger personal inspection, cargo mail inspection, aircraft guardianship and other basic operational skills, engaged in civil airport security inspection work.

\subsection{Work Tasks and Professional Capability of Civil Aviation Safety Technology Management Professional}

\section{Table 1 Summary of Job Tasks and Professional Capability of Civil Aviation Safety Technology Management Professionals}

\begin{tabular}{|c|c|}
\hline Jobs & Professional ability \\
\hline Passenger safety inspection & $\begin{array}{l}\text { 1. Familiar with document inspection responsibilities and technical requirements } \\
\text { 2. Be familiar with the duties and technical requirements of the prequel check } \\
\text { 3. Be familiar with the duties and technical requirements of security door inspection, personal } \\
\text { review } \\
\text { 4. Familiar with X-ray inspection duties and technical requirements } \\
\text { 5. Be familiar with the duties and technical requirements of the opening inspection } \\
\text { 6. Familiar with baggage inspection duties and technical requirements } \\
\text { 7. Be familiar with the use of all equipment on the site } \\
\text { 8. Responsibility, teamwork, coordination and communication skills }\end{array}$ \\
\hline $\begin{array}{c}\text { Checked baggage security } \\
\text { inspection }\end{array}$ & $\begin{array}{l}\text { 1. Familiar with X-ray machine operating procedures } \\
\text { 2. Familiar with the content of the Civil Aviation Convention (Annex 18) } \\
\text { 3. Familiar with all types of dangerous goods, contraband and restricted transport items of civil } \\
\text { aviation } \\
\text { 4. Can identify the image presented by the X-ray machine } \\
\text { 5. Familiar with the specification of communication between X-ray machine operators and } \\
\text { out-of-package inspectors } \\
\text { 6. Learn how X-ray machines deal with common problems } \\
\text { 7. Responsibility, teamwork, communication and coordination }\end{array}$ \\
\hline Aircraft monitoring & $\begin{array}{l}\text { 1. Familiar with the working procedures of aircraft guardianship } \\
\text { 2. Familiar with the disposal of people or items that are found to be suspicious or misbehaving } \\
\text { 3. Proper identification of vehicles, personnel and crew passes into the watch area } \\
\text { 4. Be familiar with and correctly identify the unit's mission statement } \\
\text { 5. Correct inspection of baggage carried by crews, staff, etc. } \\
\text { 6. Familiar with loading and unloading of aircraft cargo compartments and monitoring methods } \\
\text { for cabin working vehicles } \\
\text { 7. Responsibility, teamwork, communication and coordination }\end{array}$ \\
\hline $\begin{array}{l}\text { Crossing boundary } \\
\text { management }\end{array}$ & $\begin{array}{l}\text { 1. Can identify various types of personnel in the control area and the authenticity of the license } \\
\text { plate and the passage area } \\
\text { 2. Can perform safety inspection on items entering the control area } \\
\text { 3. Ability to analyze the geographical environment and fence protection facilities within the flight } \\
\text { control area } \\
\text { 4. According to the dynamics of the flight control area, it is possible to report irregularities, report } \\
\text { leaders in a timely manner, and take effective measures to control developments. } \\
\text { 5. Be familiar with the operation of the apron vehicle and master the key warning area. Correct } \\
\text { illegal vehicles, actively prevent vehicle traffic accidents, and maintain safe production order in } \\
\text { control areas } \\
\text { 6. Responsibility, teamwork, coordination and communication skills } \\
\text { 7. Real-time monitoring of borders and crossings to handle alarms of alarm systems in a timely } \\
\text { manner }\end{array}$ \\
\hline Security team management & $\begin{array}{l}\text { 1. Command and coordinate the tasks of safety inspectors in various classes and squadrons } \\
\text { 2. Explain questions to passengers and deal with disputes } \\
\text { 3. Accept orders from superiors, communicate various tasks and requirements to security } \\
\text { inspectors, and report problems at work to higher authorities } \\
\text { 4. Deal with emergencies and coordinate with various departments in a timely manner } \\
\text { 5. Supervise and guide the work of X-ray machine operators } \\
\text { 6. When the squad leader is not in place, replace the squad leader } \\
\text { 7. Organize and collect information in your work }\end{array}$ \\
\hline
\end{tabular}


The purpose of job assignments and professional competency analysis is to understand the specific job content of the job and the professional knowledge and comprehensive ability needed to complete the job. The object of analysis is work. The analysis of work tasks and professional abilities is the basis for formulating talent training programs. Through the analysis of work tasks and professional abilities, it is possible to summarize what knowledge, capabilities, and qualities are required for civil aviation safety inspection technical positions. This will be followed up. The establishment of curriculum system and teaching mode provide reliable and real basis. The specific steps for the analysis of job assignments and professional capabilities are to conduct surveys and analysis of one job and one job group, it sums up the required professional knowledge, operating skills and work norms one by one to form a set of job responsibilities that describe the employees to achieve their careers, and to decompose the job responsibilities of professional posts, and to complete the occupational posts comprehensive ability description. Then, each job responsibilities are further decomposed into more specific tasks, and the ability needed to complete each task is the specific ability.

Based on the analysis of professional job assignments and professional competences, a questionnaire survey was conducted on security technical positions at several domestic airports and air transport companies through careful preparation. The respondents were required to fill in the typical work done on civil aviation security inspection jobs. Tasks and the skills and knowledge required to complete these tasks. A total of 80 questionnaires were withdrawn as of October 1, 2017. On this basis, the work of the recovery questionnaire was summarized, analyzed and summarized. Then the materials will be handed over to experts in the professional teaching steering committee of the profession to allow them to make corrections, supplements, and checks. Finally, according to the opinions put forward by the experts, they have been revised and summarized, resulting in the "Analysis Table for Civil Aviation Safety Technology Management Professional Job Tasks and Professional Capability” as shown in Table 1:

\subsection{Civil Aviation Safety Technology Management Curriculum System Settings}

The curriculum issue is the core issue of whether or not civil aviation safety technology management personnel training programs can be carried out normally. Whether the construction of the curriculum system is reasonable or not is directly related to the realization of the teaching quality of civil aviation safety technology management professional and the realization of training objectives. The professional course system of civil aviation safety technology management based on the integration of education and education and production and education is the job task of the civil aviation safety technology management professional. Professional ability is the logical starting point and the main line. It integrates teaching content into industry standards, builds systematic knowledge of the work process, and jointly develops the professional ability-based curriculum system of the industry and the enterprise [3].

Therefore, with the industry experts and technicians, the work process of the civil aviation safety technology management professional corresponding to the occupation position is analyzed, the work task is decomposed for the occupational position of the civil aviation safety technical management professional, and the curriculum content is determined based on the work process of the civil aviation safety technology management position. The scope-action area is gradually reconstructed according to the law of personnel training and the development of talented professionals, making it a universal curriculum-learning field, and finally converted into a concrete learning curriculum for implementation. Through the analysis of work tasks, the typical work tasks with the content and forms of professional work were refined and the areas of professional action were merged. Break the traditional three-stage curriculum structure, according to civil aviation 
security technology management positions to the quality of the practitioners, ability, knowledge to build a systematic and comprehensive curriculum system, set up public courses, professional platform courses, professional direction courses and optional course system.

4. The Construction of Civil Aviation Safety Technology Management Talents Training Program Based on "Integration of Curriculum and Certificate, Integration of Production and Teaching"

\subsection{Government Coordination, Matchmaking, Innovation Mechanism, Integration of Production and Teaching to Promote Professional Development}

Adhere to the "school main body, civil aviation bureau coordination, industry guidance, civil aviation business participation" is an innovative mechanism for civil aviation safety technology management professional construction, we must fully guide and mobilize the civil aviation industry, enterprises and social forces to participate in professional construction and personnel training enthusiasm. The college has given strong support in terms of policies, conditions, etc.; relevant leaders of the Civil Aviation Administration visited the school to guide the professional construction and personnel training as an industry manager, and how to build a civil aviation technology application-oriented university for the future of the school and our university. Effective convergence, how to serve the industry security has been a profound analysis and elaboration. At the same time, the program actively signed a series of contracts with civil aviation related airports to jointly develop talents, introduced the industry's excellent resources into the professional talents training process, and truly realized the integrated process of industry and education.

4.2 Guided by the technical standards of civil aviation safety inspection posts, integration of production and teaching, and systematic construction of systematic teaching materials with industry and enterprises

The construction of textbooks as one of the important contents of teaching infrastructure is not only the basis for the implementation of curriculum reform and the externalization of the results of curriculum teaching reform, but also an important carrier for the innovation of personnel training models [4]. The construction of teaching materials is based on the needs of a new model of talent cultivation with "one body and two wings, learning to do oneness." Through the reform and innovation of the connotation of the teaching materials, we will lead the reform of the teaching model. From the beginning of the professional establishment, we focused on promoting the development of teaching materials for vocational education centering on work process orientation and training of professional abilities. In the construction of teaching materials, we fully reflected the curriculum organization pattern characterized by "three agreements", that is, the learning field is consistent with the field of work. Consistent with the learning process and work process, learning tasks and work tasks are consistent, highlighting the characteristics of higher vocational education; working with corporate experts and engineering and technical personnel to jointly prepare teaching materials to achieve complementary teaching resources and resource sharing.

In order to strengthen the connotation construction and take course construction as the starting point, deepen the work process-oriented curriculum teaching reform and improve the employment competitiveness of students. In order to further deepen the reform of curriculum system and teaching content, integrate curriculum resources and teachers, promote curriculum construction, and improve teaching quality. The civil aviation safety technology and management major has implemented the reform of the course system of "curriculum proof". The curriculum standards have shifted from emphasis to practice, and the main body of development has shifted from single to 
multiple. Through the establishment of a long-term mechanism for school-enterprise cooperation and development, actively absorbing industries, and enterprises participating in the formulation of curriculum standards, the integration and linking of curriculum standards and professional job skill standards are truly realized.

\subsection{Integration of production and teaching, adhering to the Principles of "Emphasizing, Introducing, Appointing, and Using Equal Stress" and vigorously developing a professional teaching team}

The key to the integration of production and teaching talents is to create professional facilities and teaching teams. The teaching team is the soul and core of education. It provides students with a steady flow of information and nutrients in the learning process, and establishes a complete education concept with rich professional knowledge. The teaching concept of avant-garde, teaching results of an efficient education team is the necessary condition for the integration of production and education, and it is also the only way for effective education. The College strengthens the construction of a teaching team for civil aviation safety technology management in a four-in-one way: Focusing on "focus on training, subject pressure, and professional guidance" as a measure, we will vigorously promote the growth and development of professional leaders; Attaches great importance to the cultivation of key teachers and promotes the overall level of professional teaching teams through demonstration and radiation; Implementation of "teaching teachers to help teach" for the construction of professional teaching team boost; Strengthen the construction of qualified instructors and form a joint force with team professional teachers.

\subsection{Keeping close to the actual project, integrating production and teaching, creating a base, and strengthening education}

In view of the special requirements for on-site safety of civil aviation safety inspection work, many job trainings cannot be carried out at the work site. This determines the importance of matching construction guidelines with work site equipment. In accordance with the concept of "integration of production and education, co-construction and sharing", we cooperated with civil aviation companies and local enterprises to build a campus training base. Starting from the three aspects of mechanism, carrier and method, fully integrate the technical standards, work standards, and management standards for safety inspection work into the whole process of professional practice teaching platform construction, personnel training, and scientific research, so as to match the professional qualities and professional skills of students with the needs of talent development in the development of civil aviation match the needs of talents, and the integration of technical achievements and practical applications. Through meticulous design, the implementation of the project is combined with the teaching cases and training content, so that the combination of teaching and production can achieve a significant improvement in the overall professional quality of students.

At the same time, in order to standardize and implement practical teaching, implement the scientific and standardized management of practical teaching work, improve the quality of practical teaching, formulate a series of practical teaching management systems, and do a good job in the construction of practical teaching systems, it ensures the effective organization of teaching according to the established syllabus and plan.

\section{References}

[1] Song Xiaoyan, Zhang Tingting. Status and demand analysis of civil aviation safety technology management 
professionals[J]. Shandong youth, 2014 (10).

[2] Liu Yan. Research on the Optimization of the International Cruise Service Professionals Training Scheme Based on Industry Standards[J]. Vocational Education News, 2015(14):13-16.

[3] Cai Zhijun. Research and Practice on the teaching mode of "integration of courses and certificates" and "two line integration" for food nutrition and Testing Specialty[J]. Journal of Anhui Agricultural Sciences, 2012(5):3023-3025.

[4] Zhang Weihua. Research on the training objectives of undergraduate applied legal talents[J]. Political Science and Law Review, 2014(3):127-135 